\title{
Internationalization and Language Policies in Brazil: What is the Relationship?
}

\section{Internacionalização e políticas linguísticas no Brasil: qual a relação?}

Felipe Furtado Guimarães*

*Universidade Federal do Espírito Santo (UFES), Vitória, Espírito Santo / Brasil felipeguim2@yahoo.com.br

http://orcid.org/0000-0001-6184-3691

Kyria Rebeca Finardi**

**Universidade Federal do Espírito Santo (UFES), Vitória, Espírito Santo / Brasil kyria.finardi@gmail.com

http://orcid.org/0000-0001-7983-2165

Janayna Bertollo Cozer Casotti***

***Universidade Federal do Espírito Santo (UFES), Vitória, Espírito Santo / Brasil janaynacasotti@gmail.com

http://orcid.org/0000-0001-7459-4268

\begin{abstract}
The article reflects on the relationship between the internationalization of higher education and language policies in Brazil. The study provides a review of language policy literature and internationalization policies materialized in national programs, such as the Science without Borders $(\mathrm{SwB})$ and the Languages without Borders $(\mathrm{LwB})$. The analysis of internationalization policies suggests that language policies are at the core of the internationalization agenda, concerning the role of English in this process; however, the role of other foreign/additional languages (L2s) still seems to be disconnected, whereby other languages lack funding and alignment with solid language policies at all educational levels. The analysis of language policies reveals the need to think about the role of L2s at different educational levels as well as in multilingualism in Brazil and in the internationalization of higher education.
\end{abstract}

KEYWORDS: internationalization; language policies; foreign languages; multilingualism. 
RESUMO: $O$ artigo reflete sobre a relação entre a internacionalização da educação e as políticas linguísticas no Brasil. Para tanto, faz-se uma revisão de literatura de políticas linguísticas e de internacionalização, concretizadas em programas como o Ciências sem Fronteiras (SwB) e o Idiomas sem Fronteiras (LwB). A análise de políticas de internacionalização sugere que as políticas linguísticas estão no cerne da internacionalização, no que se refere ao papel do inglês, entretanto, o papel das outras línguas estrangeiras/adicionais (L2s) ainda parece desconectado da internacionalização e carece de maior sintonia com políticas linguísticas em todos os níveis educacionais. Os resultados da análise apontam para a importância de pensar o papel do ensino de L2s nos diferentes níveis educacionais e também no multilinguismo no Brasil e na internacionalização do ensino superior.

PALAVRAS-CHAVE: internacionalização; políticas linguísticas; línguas estrangeiras; multilinguismo.

\section{Introduction}

The internationalization of higher education has been defined as the integration of an international, intercultural, and global dimension in the university's tripartite mission of offering education, research, and extension (KNIGHT, 2003). This integration, according to Nicolaides and Tílio (2013), can be interpreted as an informal language policy. Finardi (2016a, 2016b, 2016c) also considers that internationalization programs, such as the Sciences without Borders $(\mathrm{SwB})^{1}$ and the Languages without Borders $(\mathrm{LwB}){ }^{2}$ are evidence of language policies. Another example is the release of the 2017 Capes PrInt Public Call, ${ }^{3}$ for the internationalization of graduate programs in Brazil, which mentions the issue of language policies, as can be seen in the items transcribed and translated below (with our emphasis). This can be understood as a government strategy to induce internationalization (and language) policies in Brazilian higher education institutions:

\footnotetext{
${ }^{1}$ Internationalization program that offered scholarships for Brazilian university students (mainly at undergraduate level) to study abroad. It is also considered the largest Brazilian academic mobility plan, launched in 2011 and discontinued in 2016.

${ }^{2}$ Internationalization and languages program launched in 2012 as English without Borders, renamed Languages without Borders in 2014, to include other languages besides English. The program offers language courses (both online and face-to-face) and proficiency tests free of charge, for the academic community of partner higher education institutions. More information available at: http://isf.mec.gov.br/.

${ }^{3}$ Internationalization program launched after the discontinuity of the $\mathrm{SwB}$ and focused on the graduate level. More information available at: http://www.capes.gov.br/cooperacaointernacional/multinacional/programa-institucional-de-internacionalizacao-capes-print.
} 
3.4.1.11 The Institutional Internationalization Project shall include at least the following policies:

a) Selection of foreign partners, considering that at least $70 \%$ of the resources should be allocated to partnerships with institutions in countries with which Capes has effective cooperation (listed in Annex I), whose collaboration has shown more relevant results in quantitative and qualitative terms;

b) Internal selection of specific actions and beneficiaries, within the funding lines of the Capes-PrInt Program. In the case of cooperation projects with foreign institutions, indicate, when applicable, resource allocation plan, plan of activities, reciprocal financing, academic mobility, joint technical-scientific production, counterparts of partner institutions, among others;

c) Recruitment of lecturers with recognized scientific performance at international level;

d) Proficiency in foreign languages of students, graduate teachers and staff of the institution that have a direct relationship with the proposed Institutional Internationalization Project;

e) Recognition of credits and academic and scientific activities carried out by faculty and students abroad;

f) Welcoming and support for foreign teachers, researchers, and students;

g) Appropriation of the knowledge and experience acquired abroad by the beneficiaries of the actions of the Institutional Internationalization Project;

h) Management and operationalization of the Institutional Internationalization Project;

i) Internal monitoring and evaluation of the goals and execution of the Institutional Internationalization Project;

j) Coordination of national development programs supported by Capes to the internationalization effort. ${ }^{4}$

\footnotetext{
${ }^{4}$ In the original: O Projeto Institucional de Internacionalização deverá incluir, ao menos, políticas de: a) Escolha de parceiros estrangeiros, considerando que ao menos $70 \%$ dos recursos devem ser destinados às parcerias com instituições de países com os quais a Capes mantém cooperação efetiva (listados no Anexo I), cujas colaborações tenham mostrado resultados mais relevantes em termos quantitativos e qualitativos. b) Seleção interna
} 
7.3. The Institutional Project must be filled out in an electronic form, in English and in Portuguese. ${ }^{5}$

Having outlined this panorama, this study intends to discuss the relationship between internationalization and language policies materialized in educational reforms and governmental programs. To do so, we first present a brief review of concepts and studies on internationalization and then review language policies implemented in educational reforms, such as the conversion of Bill Number 746/2016 into Law Number 13,415, passed in 2017, and in government programs, such as the SwB and LwB, to conclude with an attempt to answer the research question that motivated this paper. By analyzing studies related to the topics described above, along with documents and projects launched by the Brazilian government, this paper becomes part of a series of studies developed by a research group ${ }^{6}$ established at a university in southeastern Brazil, the region with the highest number of higher education institutions (HEIs). This group investigates the connections between internationalization and policies, along with higher

de ações específicas e beneficiários, dentro das linhas de financiamento do Programa Capes-PrInt. No caso de projetos de cooperação com instituições estrangeiras, indicar, quando houver, plano de aplicação de recursos, plano de atividades, financiamento recíproco, mobilidade acadêmica, produção técnico-científica conjunta, contrapartidas das instituições parceiras, entre outras; c) Contratação de professores com reconhecido desempenho científico em nível internacional; d) Proficiência em línguas estrangeiras dos discentes, docentes de pós-graduação e corpo técnico da Instituição que tenha relação direta com o Projeto Institucional de Internacionalização proposto; e) Reconhecimento de créditos e das atividades acadêmicas e científicas realizados por docentes e discentes no exterior; f) Acolhimento e acompanhamento de docentes, pesquisadores e discentes estrangeiros; g) Apropriação do conhecimento e experiência adquiridos no exterior pelos beneficiários das ações do Projeto Institucional de Internacionalização. h) Gerenciamento e operacionalização do Projeto Institucional de Internacionalização; i) Acompanhamento e avaliação interna das metas e da execução do Projeto Institucional de Internacionalização. j) Conciliação de programas nacionais de fomento apoiados pela Capes ao esforço de internacionalização.

${ }^{5}$ In the original: O Projeto Institucional de Internacionalização deverá ser preenchido no formulário eletrônico, em inglês e em português.

${ }^{6}$ CNPq Research Group entitled "Internationalization and Technologies", registered at UFES. More information available at: http://dgp.cnpq.br/dgp/faces/home.jsf?facesredirect $=$ true. 
education and languages, in order to produce knowledge in a field that only recently has acquired a fundamental role in the management of Brazilian universities.

\section{Internationalization}

For a broader public, the internationalization of higher education is a relatively recent process that began some 30 years ago (DE WIT, 2016), and whose centrality is an unequivocal reality (LAUS, 2012). Internationalization, often understood as international cooperation and academic exchange between higher education institutions in different countries, has been seen as an important strategy for the development of higher education institutions (CARVALHO; MAIA, 2015). Yet this view of internationalization is challenged by a group of researchers who affirm that not all the effects of internationalization are positive, since such effects may represent a form of colonization (CASTRO-GÓMEZ, 2007), which is often violent (ANDREOTTI et al., 2015) and oppressive.

Regardless of the view of internationalization, it is important to note that this process goes far beyond the notion of cooperation and academic mobility, as suggested by De Wit et al. (2005), in a study financed by the World Bank. The author also reminds us that internationalization is often seen as synonymous with international education, international cooperation, global education, multicultural education, transnational education, education without frontiers, overseas education, and cross-border education, and must have a clear objective that benefits the community in question. As suggested by Finardi and Guimarães (2017), other authors, such as Jenkins (2013), see internationalization as synonymous with globalization, while Menezes de Souza (2015) understands that the internationalization process is so linked to globalization that it is difficult to know if it is a consequence or cause of globalization.

According to Finardi, Santos and Guimarães (2016), in relation to the suggestion of De Wit (2016) about the goal of internationalization, it is important to bear in mind that many European universities started the process of internationalization with a financial (in addition to academic) objective. As reviewed in Finardi and Guimarães (2017), according to Vavrus and Pekol (2015), this coincided with the neoliberal decline in public funding for universities, forcing these institutions to seek external funding sources, 
such as tuition fees from foreign students. Thus, it is not simply a question of distrusting the objectives of internationalization, but rather of analyzing the context of this internationalization for higher education institutions and, consequently, what their objectives and benefits would be (FINARDI, 2017a) for the academic (and local) community and society at large.

Based on the assumption that Brazilian universities have different motivations for internationalization, Finardi and Ortiz (2015) analyzed the internationalization process of two Brazilian universities, one public and one private, proposing a hypothesis that the private university would have more (economic) motivation for internationalization than the public one, since the latter does not depend on financing from (foreign) student fees. However, this hypothesis was completely refuted in that study, whose results indicated that the public university had more (academic) motivation for internationalization, since the Brazilian internal market is very comfortable for private universities that do not need to seek external financing (in the form of monthly fees) outside the country, given that the number of Brazilian students in private institutions is much higher than in public institutions. In addition, Brazil has a very large internal market in terms of total population and number of university students.

In fact, we can identify several motivations for internationalization can be identified, and the academic and economic objectives are merely two aspects of this process. Taquini, Finardi and Amorim (2017) analyzed the offer of courses in English (English Medium Instruction or EMI) of Turkish universities, contrasting these results with the reality in Brazil. Their study was carried out at a key political moment for Turkey, which was applying for entry into the European Community, thereby suffering internal and external pressure both to Westernize and to maintain its Eastern culture and references. Results of their study showed that Turkey, unlike Brazil, has more public higher education institutions and that the main motivation for the internationalization of its institutions was to enter the European Community.

As it is, the question of motivation for the internationalization of higher education, despite De Wit's (2016) suggestion that it should always have the academic improvement of the target community as the main objective, often has other motivations. Another issue in which there seems to be no consensus regards the definition of internationalization. As we can see in Table 1, the issue seems to raise many interpretations. 
TABLE 1 - Internationalization Definitions (1992-2002)

\begin{tabular}{c|l|l}
\hline Year & \multicolumn{1}{|c|}{ Author } & \multicolumn{1}{c}{ Definition } \\
\hline 1992 & $\begin{array}{l}\text { Arum and Van } \\
\text { de Water }\end{array}$ & $\begin{array}{l}\text { The multiple activities, programs, and services that are } \\
\text { included in international studies, international educational } \\
\text { exchanges, and technical cooperation. }\end{array}$ \\
\hline 1994 & Knight & $\begin{array}{l}\text { The process of integrating an international and intercultural } \\
\text { dimension into the teaching, research, and services functions } \\
\text { of an institution. }\end{array}$ \\
\hline 2002 & Soderqvist & $\begin{array}{l}\text { Any systematic effort to make higher education responsive } \\
\text { to the demands and challenges related to the globalization of } \\
\text { societies, the economy, and labor markets. }\end{array}$ \\
\hline $\begin{array}{l}\text { A process of moving from a national institution of higher } \\
\text { education to an international institution of higher education, } \\
\text { leading to the inclusion of an international dimension in all } \\
\text { aspects of its holistic management, in order to improve the } \\
\text { quality of teaching and learning, and achieve the desired skills. }\end{array}$
\end{tabular}

Source: Adapted from de De Wit et al. (2005, p. 11-13)

In an attempt to encompass all these dimensions, Hudzik (2011, p. 6) defines internationalization as:

Comprehensive internationalization is a commitment, confirmed through action, to infuse international and comparative perspectives throughout the teaching, research, and service missions of higher education. It shapes institutional ethos and values and touches the entire higher education enterprise. It is essential that it be embraced by institutional leadership, governance, faculty, students, and all academic service and support units. It is an institutional imperative, not just a desirable possibility. Comprehensive internationalization not only impacts all of campus life but the institution's external frames of reference, partnerships, and relations. The global reconfiguration of economies, systems of trade, research, and communication, and the impact of global forces on local life, dramatically expand the need for comprehensive internationalization and the motivations and purposes driving it. 
Beelen and Jones (2015) focus more on the notion of "internationalization at home", 7 understood as the intentional integration of international and intercultural dimensions into the formal and informal curriculum for all students within the domestic learning environments. A more recent definition, proposed by De Wit in the area of educational policies (EUROPEAN PARLIAMENT, 2015, p. 29), reviews Knight's (1994) definition to advance the following:

Internationalization at Home is the purposeful integration of international and intercultural dimensions into the formal and informal curriculum for all students within domestic learning environments.

Notwithstanding myriad of definitions of internationalization found in the literature, in this study, we chose De Wit's definition (2016) because we understand that it is both comprehensive and synthetic enough, and because it was defended by the author in an event about internationalization, called "Impact of Internationalization on the Quality of Higher Education", held in 2016 at Unicamp by the Interuniversity Development Center (CINDA).

Internationalization has been at the top of higher education priorities and, in a positive light, it becomes a relevant mechanism for social change (ROBERTSON, 2010). However, Garson (2016) indicates that internationalization has also become an industry to generate revenues for educational institutions, as pointed out earlier in this text regarding the motivation of internationalization. When studying this process in Canada, the author identifies that the focus has been to increase the number of foreign students enrolled, in the same way as described by Finardi, Santos and Guimarães (2016) and Finardi and Ortiz (2015).

As some of us have suggested before and elsewhere (for example FINARDI; GUIMARÃES, 2017; GUIMARÃES, 2016), internationalization, often equated with the concept of globalization (JENKINS, 2013), yields benefits and negatives impacts. Among the factors to be improved in this process, the International Association of Universities (IAU, 2012) presents issues such as inequalities and limited access to education. This is because not all students are able to pay for this internationalized education,

\footnotetext{
7 Available at: http://www.universityworldnews.com/article.php?story $=20151202$ 144353164. Retrieved on: Nov. 2, 2016.
} 
thus increasing the "social gap" and the risk of education becoming commodified, driven by globalization, as already described in the case of English (FINARDI, 2014, PORCINO; FINARDI, 2014). To avoid this negative impact, some authors (DE WIT, 2016) advocate a greater internationalization at home and the use of hybrid approaches (such as Collaborative Online International Learning - COIL - which will be explained later in this paper) that allow the exchange of information and research, even in (and perhaps specially in) contexts with limited resources to finance physical academic mobility.

Regarding the possibilities of information exchange, Kumaravadivelu (2006, p. 131) points out the current characteristics of the globalization process, such as the shortening of spatial distance, the reduction of timerelated distance, and the disappearance of borders. He points out that one of the most distinctive features of the current process is electronic communication via the internet, with English being the language of globalization. For some time now, the role of English in the access to information (FINARDI; PREBIANCA; MOMM, 2013), to online education (FINARDI; TYLER, 2015), in the production and circulation of knowledge (FINARDI; FRANÇA, 2016), and in the process of internationalization (FINARDI; SANTOS; GUIMARÃES, 2016; FINARDI, 2017b; FINARDI; GUIMARÃES, 2017) has been discussed. In addition, these authors advocate the "horizontalization" of education with broader opportunities through the use of hybrid approaches (FINARDI; PREBIANCA; SCHMITT, 2016; PREBIANCA; CARDOSO; FINARDI, 2014), which, as we shall see later, can also be used in favor of a comprehensive and inclusive internationalization.

As put forward by Finardi and Guimarães (2017), Northern and Western dominance in the process of globalization/internationalization is questionable as universities in the North and in the West dominate research activities and sources of finance (GARSON, 2016). According to Finardi and França (2016), this domination is also questionable, since Brazil, for example, despite being one of the thirteen countries with the largest academic production in the world, has no world-class universities and has little impact in the overall global academic production. These authors explain that one of the reasons for this discrepancy between scientific production (quantity) and international impact (quality) is largely due to the language in which most of the national production is published. In this same line of reasoning, 
Vavrus and Pekol (2015) say that globalization/internationalization benefits the North more than the South, whereas Hamel (2013) explains that one of the reasons for that imbalance is the linguistic bias whereby Anglophone countries and those that adopt English as an academic and instructional language (JENKINS, 2013) have more prominence over those that do not.

De Wit (2016) also mentions that international cooperation in Latin America has occurred unilaterally, especially with the United States and European countries. He points out the need for Latin American countries to develop more cooperation among themselves, considering South-South cooperation, following that proposed by Vavrus and Pekol (2015) and Finardi, Santos and Guimarães (2016), which Stein et al. (2016) and Finardi (2017a) call critical internationalization.

In the exact opposite direction, the Capes PrInt Call, in the list of priority countries for the internationalization of Brazilian graduate programs, identifies the following: South Africa, Germany, Argentina, Australia, Austria, Belgium, Canada, China, South Korea, Denmark, Finland, France, Germany, India, Ireland, Italy, Japan, Mexico, New Zealand, Norway, Spain, Sweden, Switzerland, the United Kingdom, and the United States of America. We can see that, of the 26 countries listed above, 15 are located in Europe and 2 in North America, with only 4 countries in the Southern Hemisphere, though 2 of these are in the Global North ${ }^{8}$ (SANTOS, 2011).

As reviewed in Finardi and Guimarães (2017), Stein et al. (2016) suggest analyzing the internationalization of higher education critically, considering the intentions and results of this process, in order to avoid the negative effects of internationalization. Stein et al. (2016) propose the analysis of the patterns of educational engagement through a social cartography, with four possibilities of the articulation of internationalization. The first articulation, called internationalization for global knowledge economy, sees higher education as key to the success of global knowledge economy, and higher education in this sense is vital for both national economic growth and competitiveness through the production of research, inventions, and innovations. Certain areas, such as technology, engineering, and mathematics, are favored over other human and social areas. In this view, academic mobility serves to prepare students for the global job market. In

\footnotetext{
${ }^{8}$ Santos (2011) uses this term to refer to central countries, despite their geographical location, since this is a geopolitical term.
} 
Brazil, we can see evidence of this articulation of internationalization in such programs as Science without Borders, which prioritized outgoing academic mobility. In this paradigm, teacher success is measured by research products with the potential to generate revenue, by publications in international journals and by collaborations with well-ranked international institutions.

The second articulation sees internationalization as a global public good that is fundamental for the production of public goods, such as democracy, prosperity, and knowledge. To illustrate this articulation, Stein et al. (2016) cite the example of the campaign launched by the Association of English-speaking Universities to raise awareness of how higher education can and should respond to today's challenges in the anticipation of the United Nations' sustainable development goals. The campaign is based on the assumption that universities are the main producers of appropriate and relevant knowledge to solve the current challenges of poverty, (in) environmental sustainability, and epidemics. This articulation can be seen in the results of Capes' proposals for financing privileged projects that sought to provide a solution for these kinds of problems, such as the study of vaccines against Zika or Dengue, two epidemics that have recently impacted Brazil.

The third articulation, called anti-oppressive internationalization, is based on solidarity in favor of systemic change in order to achieve social justice. This view criticizes the concept of global knowledge economy for its uncritical support of capitalism. The anti-oppressive view challenges internationalization practices that emphasize access, requiring selective denial or "depoliticization" of difference, motivating compliance with educational standards or modes of knowledge production from the West. In doing so, this strand criticizes the previous two and questions the benevolence of higher education, widely assumed by the global knowledge economy and the articulation of internationalization as a public good. This strand defends those who are presumably undermined by internationalization programs and policies, such as overseas volunteer programs that may exploit or be harmful to local communities, as well as promote an elitist and exclusivist cosmopolitanism, perpetrating Western visions, and preventing international students from questioning how their positions within a global economy can contribute to the damage they try to correct with their trips abroad.

We can somehow associate this criticism with the Science without Frontiers program, which privileged only one area of knowledge to the 
detriment of others, as well as promoted the exclusion of some parts of the population that were not covered by the program. The aim of this articulation would be to make students aware of their complicity in local and global damage, as well as to bring knowledge from the periphery to the center, rather than export knowledge from the center to the periphery. As such, this view is contrary to the Eurocentric universalism that underlies evaluation systems through university rankings, as discussed by Finardi and Guimarães (2017), as well as educational policies of organizations such as the World Bank and the Organization for Economic Co-operation and Development (OECD).

To illustrate this aspect, as reviewed in Finardi and Guimarães (2017), Stein et al. (2016) describe the example of the Federal University of Latin American Integration (UNILA), an interregional university created in 2007 on the common border of Argentina, Brazil, and Paraguay, as part of the third cycle of higher education expansion in Brazil. The authors explain that the first cycle of expansion focused on the expansion of access, while the second cycle focused on the restructuring of existing universities. Unlike other universities in Brazil, UNILA offers bilingual education to other Western universities, since it positions itself against hegemonic tendencies, and its mission does not include aspirations of leadership, prestige, or economic imperatives. According to the authors, UNILA's orientation is a good example of how an institution can rethink the patterns of internationalization and domain replication.

The fourth articulation, that of relational translocalism, is what Stein et al. (2016) think is possible for internationalization within the logic of contemporary global capitalism. As in the anti-oppressive articulation, there is a recognition here of the domain patterns and of what cycles of violence are produced by this logic. However, in addition to criticizing such logic, there is a commitment to recognize the complicity of each. Proponents of this strand are disappointed not only with the content, but also with the form of global internationalization, which is acknowledged as being unsustainable and harmful, by providing prosperity and security for some to the detriment of others who are subject to violence. The authors conclude that their experiments with social cartography were motivated by the desire to leave their comfort zones and the vision of the internationalization of higher education that reaffirms benevolence, redemption, innocence, a vision of 
new possibilities of understanding that take account for the complexity, tension, difficulties, and paradoxes embodied in the theme.

In Brazil, the issue of the internationalization of higher education gained great prominence with the advent of the Science without Borders program, whose main objective was to finance outgoing mobility. The mobility of Brazilian students and teachers has also been financed, albeit to a lesser extent, by development agencies such as Capes $^{9}$ and $\mathrm{CNPq},{ }^{10}$ which have a track record of supporting international research partnerships (FAUBAI, ${ }^{11}$ 2016), including those prior to SwB. Regarding SwB, it is important to note, as we have previously done (for example FINARDI; GUIMARÃES, 2017), that this was the largest investment ever made by Brazil to encourage internationalization through outgoing mobility. We can say that the SwB was responsible for raising awareness on the role of foreign languages in the process of internationalization, culminating in the creation of the English without Borders program in 2012, renamed Languages without Borders (LwB) in 2014. According to educational stakeholders present at the internationalization seminar held in October 2016 at Unicamp, one of the greatest benefits of the SwB was the awareness of the important role of internationalization itself and outside the environment of large Brazilian universities that had already been internationalized before SwB.

Still in the Brazilian context, and according to Finardi and Guimarães (2017), some provisions have been adopted to promote internationalization, despite the obstacles, such as the high U.S. dollar/Brazilian real exchange rate and the Brazilian economic crisis. In a report by Folha de São Paulo about university courses taught in English as a strategy to attract more foreigners to study here, data reveal the types of courses taught in English in Brazilian institutions: short-term courses (62\%); undergraduate, regular, or elective courses $(30 \%)$; graduate school courses, whether regular or elective $(7 \%)$; complete graduate programs $(0.9 \%)$ and full undergraduate programs $(0.1 \%)$. An equal distribution can also be found in the areas in which these courses are taught, as follows: applied social sciences (32\%); linguistics, languages and arts (21\%); health (8\%); exact sciences and geosciences $(8 \%)$;

\footnotetext{
${ }^{9}$ Coordination for Development of Higher Educational Personnel in Brazil (http://www. capes.gov.br/)

${ }^{10}$ National Council for Scientific and Technological Development in Brazil (http:/ / cnpq.br/)

${ }^{11}$ Brazilian Association for International Education (http://faubai.org.br/en-us/)
} 
agrarian sciences (7\%); engineering (6\%); and other areas $(18 \%)$. The $\mathrm{ABC}$ Federal University stands out in this context as the institution that offers the most courses in English: 103.

In a national survey on EMI (English Medium Instruction) courses, Martinez (2016) indicates that the offer of undergraduate courses in English in Brazil is still low, as can be seen in the table below.

TABLE 2 - Universities that offer classes in English at the undergraduate level (2010-2016)

\begin{tabular}{|c|c|c|c|c|c|c|}
\hline 2010 & 2011 & 2012 & 2013 & 2014 & 2015 & 2016 \\
\hline $\begin{array}{l}\text { FEA- } \\
\text { RP USP }\end{array}$ & $\begin{array}{l}\text { PUC } \\
\text { Paraná }\end{array}$ & FAE & $\begin{array}{l}\text { PUC Rio } \\
\text { Grande } \\
\text { do Sul }\end{array}$ & $\begin{array}{l}\text { - Universidade } \\
\text { Federal de } \\
\text { Viçosa } \\
\text { - Universidade } \\
\text { Federal do } \\
\text { ABC } \\
\text { - USP } \\
\text { - UTFPR }\end{array}$ & $\begin{array}{l}\text { - Universidade } \\
\text { Regional de } \\
\text { Blumenau } \\
\text { - Fundação } \\
\text { Getúlio } \\
\text { Vargas } \\
\text { - Univates }\end{array}$ & $\begin{array}{l}\text { - Universidade do Estado de } \\
\text { Santa Catarina } \\
\text { - Universidade Federal do Paraná } \\
\text { - Universidade de Fortaleza } \\
\text { - Universidade Federal } \\
\text { Fluminense } \\
\text { - UNIFACS } \\
\text { - Universidade Federal de Ouro } \\
\text { Preto }\end{array}$ \\
\hline
\end{tabular}

Source: Adapted from Martinez (2016, p. 207)

A more recent account of the courses and academic activities offered in English in Brazilian higher education institutions, published by the British Council and Faubai ${ }^{12}$ as a Guide in 2018, launched in the EAIE 2018 edition ${ }^{13}$ in Geneva, and presented in the $1^{\text {st }}$ Brazilian English Medium Instruction Seminar ${ }^{14}$ held in Curitiba, shows an increase in the offer of courses and activities in English in Brazil. The authors of this guide, one of whom is an author of this paper, also collected data on other languages used in Brazilian higher education institutions and, with the support of the other members of the Faubai working group for languages, is currently analyzing the results of the survey carried out in 2017 regarding the use of languages in Brazilian higher education institutions.

\footnotetext{
${ }^{12}$ Available at: http:/ / faubai.org.br/britishcouncilfaubaiguide2018.pdf

13 Available at: https://www.eaie.org/geneva.html

${ }^{14}$ Available at: http://bemis2018.weebly.com/
} 
It is worth noting that, influenced by economic motivations, knowledge of English is considered essential for participation in a globalized world, where it acts as a lingua franca (GIMENEZ et al., 2011), as well as in Brazil, where it acts as both an international language (FINARDI, 2014) and a foreign/additional language (FINARDI, 2016c, FINARDI, ARCHANJO, 2015). Finardi and Csillagh (2016) argue that no study on the role of languages in the internationalization process can be done without considering the role of English in it. As suggested by Finardi and Guimarães (2017), the distinctive character of this language in relation to other L2s in Brazil, reinforced by economic globalization, became more visible in such programs as the SwB (Gimenez, 2013) and the LwB (FINARDI, 2016a, FINARDI, ARCHANJO, 2018).

Globalization also promotes a privileged status vision for the knowledge of L2s (FINARDI, 2016c), placing English in a central position for communication between speakers of different languages (MONTE MOR, 2013), besides its status of cultural capital and its status as a requirement for an economic upswing. For Sarmento, Abreu-e-Lima and Moraes Filho (2016), the current motivation to learn English, for example, can be explained by the desire to compete in the labor market to acquire social distinction.

In addition to the actions aimed at teaching English, such institutions as the International Francophone Organization and the German Academic Exchange Service (DAAD) have developed actions to promote the internationalization of higher education through other languages. In October 2016, the Brazil-Germany Network for the Internationalization of Higher Education (REBRALINTES) was established, seeking to unite cooperation experiences, take advantage of existing exchange mechanisms, and share information to connect DAAD and Brazilian universities, according to information from Martina Schulze, Director of the DAAD Office in Brazil, available on the DAAD Brazil website. The DAAD was also the body responsible for mediating relations between $\mathrm{SwB}$ fellows and German institutions.

To create better learning conditions, the DAAD has maintained agreements with language institutes to deal with the different levels of proficiency of German scholarship holders (DAAD, 2015). There were German language courses before the scholarship holders attended the academic subjects, as well as an online course called DUO (Deustch-Uni 
Online). To promote the interest of Brazilian students in studying in Germany, the teaching of German has been supported by young German teaching assistants through a program that the DAAD developed for Brazil in 2013 (DAAD, 2015), in a similar format as practiced by Fulbright / Capes American Fellows of the LwB Program.

In the case of French, the French-speaking international movement and several universities have promoted the L2 teaching approach known as the inter-comprehension approach (FINARDI, 2017b), including it through Massive Online Open Courses (MOOCs), such as the MOOC to use the inter-comprehension approach in the teaching of Romance languages (as in the case of French, Italian, Portuguese, and Spanish) simultaneously (FINARDI, 2016d). In addition to this measure, and as further reported by Finardi (2017b), French-speaking universities have developed language policies to protect French as a language of instruction, administration, admission, and research.

With regard to Portuguese as an additional language (PAL), there are also actions both in the internal and external contexts. In the internal context, in addition to the projection of Celpe-Bras as a reference exam in teaching Portuguese to foreigners in Brazil and abroad, there are also Brazilian universities involved in teaching PAL. According to Carvalho and Schlatter (2011), the Celpe-Bras generated several discussions about teaching practices in the PAL area and encouraged research on teaching, learning, and evaluation in the field. Among the teaching and research groups in Brazil, the University of Brasilia (UnB), the State University of Campinas (Unicamp), and the Federal University of Rio Grande do Sul (UFRGS) have teams with extensive experience in the area. Other universities worth mentioning are PUC-SP (through NUPPLE), PUC-RJ, UFBA (through PROPEEP), UFF, UFMG, UFPR (through CELIN), UFRJ, and UFSC. There are also those that have begun to develop research: UEL (through the Language Laboratory-IRCH), UFAM, UFSCar, UNIPAMPA, UNESP, and USP (CARVALHO; SCHLATTER, 2011, 272). Many higher education institutions in Brazil today offer Portuguese as a foreign language (PFL) course for foreigners, since this is one of the requirements to offer the Celpe-Bras exam.

In addition to the PAL actions related to Celpe-Bras, the LwB program understands that the teaching of Portuguese as a foreign language (PFL) is strategic to leveraging the internationalization process (at home) in 
Brazil. Thus, the LwB's Public Call for a Federal University Re-accreditation program launched in 2017, which, like the Capes PrInt Call, had an inductive nature (in this case of language policies and in the case of the PrInt Call for internationalization policies), PFL played a prominent role, as did English, in relation to other languages. The proposal foresees that the universities could make three types of proposals: the first was to offer only English; the second was to offer English and PFL; and the third was to offer English, PFL, and other languages (French, Spanish, Italian, German, or Japanese). The Call also required the approval of an institutional language policy, in the same way that the PrInt Call required the approval of an institutional internationalization policy to submit a proposal.

In the external context, Nóbrega (2016) indicates that there are Portuguese courses taking place in many places around the world. More specifically in higher education institutions, there are regular courses offered in several institutions such as: at the universities of Yale, Princeton, Cornell, Brown, Georgetown (USA); Oxford and Cambridge (England); Stockholm (Sweden); Aarhus (Denmark); Oslo (Norway); and Salamanca (Spain).

Among the many reasons why foreigners seek to learn Portuguese, the author specifies at least four: a) the possibility of development of heritage language that motivates the children of Portuguese-speaking immigrants to learn Portuguese; b) involvement with cultural goods, such as Brazilian music and movies; c) the interest of professionals who wish to work in Brazilian companies based abroad, or even foreigners who intend to study or work in Brazil; and d) the interest of translators, interpreters, teachers of Portuguese for foreigners who want to improve themselves in the exercise of their profession. To these advantages we would like to add the possibility of internationalizing "at home", as suggested by Beelen and Jones (2015). There are, therefore, varied motivations and heterogeneous public to learn PFL. Thus, the author indicates the need to better characterize the interests of each of these groups to contribute to the development of the area. The author also says that, regarding PAL, even if development has been made, it is necessary to continue making progress (NÓBREGA, 2016, p. 433).

Despite the growth of internationalization at the global level and in Brazil, driven by the $\mathrm{SwB}$, there are some challenges to be overcome in this process (DE WIT, 2016), namely: 
- the existence of bureaucratic obstacles, mismatch between the financing models of Higher Education and outsourcing to external entities;

- increasing numbers of unethical practices, fraud and corruption, by different stakeholders;

- a dominant focus on mobility, accessible only to a small elite, not integrated into the curriculum / teaching / learning, and the lack of engagement of teachers and staff in this mobility;

- lack of integration among institutional, national, and supranational policies.

At national levels, we can list the following challenges (KAMIENSKI, 2016):

- developing proficiency in English;

- national (and not global) focus of most universities;

- creating an international environment at home.

Besides these challenges, Nicolaides and Tílio (2013, p. 296) refer to the following:

a) Brazilian students do not yet have much tradition (at least before the SwB Program) to study abroad, and Brazil is still not a highly sought after destination by foreign students, considering the dimensions of the educational system in Brazil;

b) language barriers in universities that resist offering courses in English;

c) bureaucratic obstacles to the granting of visas to foreigners coming to study in Brazil;

d) lack of housing, since few universities offer housing and real estate companies ask for documents that foreigners usually do not own.

In view of the challenges to internationalization related to the knowledge / use of L2s, the next section will review the language policies in Brazil to reflect on the relationship between them and the internationalization process. 


\section{Language Policies}

To define language policies (LP), Rajagopalan (2013) clarifies that this is a more complex issue than those who associate it with "linguistic advocacy" may think. As the linguist explains:

[...] advocacy is part of what we call language policy; but it is important to stress that it is only a small part, although vital. The field of language policy covers much more than advocacy. And, of course, it is not restricted to political activism in favor of this or that cause involving linguistic issues." (RAJAGOPALAN, 2013, p.19, our translation).

Rajagopalan argues that, unlike the name suggests, language policies are not strictly linked to Linguistics. Instead, language policies are a "branch of politics", a "political science", a "field of activity" that refer to decisions made at the macro level as well as to activities that enable the implementation of these decisions (language planning). According to this linguist, language policies constitute a "field of political action", that is, the choice that defines a given decision among several possibilities is eminently political. Rajagopalan also states that, in the context of language policies, many decisions can be taken and implemented from the top-down, or from the bottom-up.

The latter, however, do not have the same repercussion as the former, since they are linked to social practices that are becoming common in the community and end up consecrating a given norm. In one way or another, the unfolding of a given language policy, however well intentioned, may indicate that the choice was right or wrong, above all because, in this field of knowledge, it deals with perceptions and values and not with facts, with absolute certainties. In this sense, language policies are interventional and, unlike Linguistics, seek, through the perception of a given linguistic reality, to intervene in it.

Spolsky (2004) states that language policies are created and discussed in a complex scenario of cultural, educational, demographic, religious, economic, political, and social factors. Due to the centrality of language to education (SPOLSKY, 2004), many of these discussions occur around the choice of the language(s) to be used as the medium of instruction (in the present study, we focus on the medium of instruction in higher education). This author indicates three key components to understand the language policy of a given speech community: a) language practices - selecting the 
varieties to make up the repertoire; b) language beliefs/ideologies - what people think of language use; c) efforts to influence language practices: intervention, planning, and management.

One should notice that many groups try to manipulate language uses and practices (through policies) in order to "promote political, social, economic, and personal ideologies" (SHOHAMY, 2006, p. xv). Thus, language policy happens in the midst of battles between ideologies and practices, through overt and covert mechanisms. This author adds that LP are used to create group membership, demonstrate inclusion/exclusion, show economic status and classify personal identities, among other uses and practices regarding language.

To understand language policies, it is also important to consider the relations between a given language and its roles in a given society (RICENTO, 2006). This author explains that the role and status of a language is usually related to its social use, as well as to political ideology. In addition, language policies and planning usually take place in multilingual scenarios, where "planning for one language has repercussions on other languages and ethnolinguistic groups" (RICENTO, 2006, p.5), and this planning reflects relations of power among various groups, as well as social, political, and economic interests.

The relevance of this theme-language policy-makes us contemplate the school context and, as Nicolaides and Tílio (2013) argue, about our commitment to problematize issues that have been perpetuated in Brazilian basic education, such as the belief that it is not possible to learn foreign languages fluently in schools. Still, according to Nicolaides and Tílio (2013), the applied linguist should intervene and act directly on language policies to preserve and recognize minority languages (indigenous, immigration, sign languages) and language teaching policies.

Hence, research is important, as it contributes to the broadening of the discussions on language policies, both in the academic context, in the initial education for teachers, for example, and in the school context, thus reducing the distance between the university and the school (FINARDI; DALVI, 2012).

Although the first studies in the area took place in the 1960s, as shown by Ribeiro da Silva (2013), in order to solve "linguistic problems" in the process of the decolonization of regions in Africa and Asia, in Brazil, the theme, according to Nicolaides and Tílio (2013), has called the attention of 
applied linguists since the beginning of the 1990s, with activities promoted by the Brazilian Association of Applied Linguistics (ALAB), which, in 2013, achieved great impacts with the organization of the $10^{\text {th }}$ Brazilian Congress of Applied Linguistics (CBLA), held in Rio, with the theme "Politics and Language Policies".

However, some authors, such as Bagno and Carvalho (2015) and Souza (2014), state that the subject of language policies in Brazil dates back to the colonial period, a period of repression and imposition of a language over others. During the $18^{\text {th }}$ century, the colonial government banned the "general language", taught by Jesuits and based on the Tupi language (one of the indigenous peoples from Brazil). The variety of Portuguese taught for decades in Brazil was based on the Portuguese literary model from the $19^{\text {th }}$ century - something very distant from the reality of Brazilian students. During the government of President Getulio Vargas, German and Italian varieties, spoken in Southern Brazil, were banned for ideological reasons. These are a few examples of how language policies have had an impact on Brazilian history.

Despite the plurality that characterizes Brazil, the myth of monolingualism still continues to be repeated so as to mark a "linguistic territory" that is intended to be uniform. Likewise, language policies seem to delay recognizing the existence of multilingualism and plurilingualism so characteristic of our country, despite some exceptions, including the National Inventory of Linguistic Diversity in December 2010.

Recently, the Federal Government approved the Bill (MP 746/2016) that was transformed into Law Number 13.415, ratified on February 16, 2017, which defined a policy for the teaching of L2s in Elementary Education. Previously, according to the (LDB), the teaching of L2 was compulsory from the $6^{\text {th }}$ year on, the former $5^{\text {th }}$ grade in the LDB writing. However, schools could choose the language offered, according to "the possibilities of the institution". In high school, the foreign language was a compulsory subject, but the school community could define the language and could also choose whether or not to teach an L2. Souza (2014) indicates that, in spite of the need to promote multilingualism (due to internationalization and academic mobility), language policies in Brazil seemed to favor only English and to a much lesser extent, Spanish.

In 2005, Law Number 11,161 expressively suggested the teaching of Spanish, indicating it as the L2 to be offered in high school. Although the 
offer was mandatory, students could choose another language offered in schools. The fact is that, in practice, there have never been so many options for that choice.

With the reform of 2017, English becomes the mandatory L2 both in elementary school (from the sixth year on) and in high school. In Secondary Education, specifically, there may still be a second language offer, preferably Spanish.

In the context of the devaluation of the teaching of L2s in the Brazilian educational system by a lack of language policy, Sarmento, Abreu-e-Lima and Moraes Filho (2016, p. 27) indicate the need to establish policies for teaching L2s. Even with the existence of documents that guide the teaching of L2s in Brazil, it is not yet possible to state that there is a formalized and unified national policy for teaching L2s, since the existing documents do not seek to promote conditions for articulated actions.

Indeed, Finardi and Archanjo (2015), in an analysis of language policies for the teaching of L2s in Brazil, conclude that there is a policy for elementary schools, another for high schools, and yet another for higher education. This "schizophrenia" of language policies for the teaching of L2s at different levels of Brazilian education seems to corroborate the suggestion of Abreu-e-Lima and Moraes Filho (2016), Finardi (2016a) on the need for reflection and proposition of language policies converging with internationalization actions and integrated at all levels of Brazilian education. To this reflection, we add the need to think critically about internationalization.

As for institutional policies to promote $\mathrm{L} 2$ teaching in favor of internationalization, Kamienski (2016) cites the example of the Federal University of $\mathrm{ABC}$ (UFABC), which has offered academic courses in English since the end of 2014. According to the author, this action was inevitable for the "at home" internationalization of this institution. It should be noted that at UFABC there has been an experience with COIL (Collaborative Online International Learning) methodology in which students and teachers from different institutions interact in a network, through English, to learn academic contents. These hybrid approaches for teaching have been widely used for internationalization when there are not enough financial resources for de facto academic mobility. According to Finardi (2017a), hybrid approaches can and should be used to stimulate critical and more sustainable internationalization in home models. 
According to Sarmento, Abreu-e-Lima and Moraes Filho (2016), the rapid expansion of the internationalization of higher education in Brazil over the past five years has resulted in a growing search for language learning with more and more parents seeking to enroll their children in these courses. Guidelines developed by UNESCO also emphasize that the intensification of relations between countries has promoted the learning of other languages (SARMENTO; ABREU-E-LIMA; MORAES FILHO, 2016).

In an increasingly interconnected world, in a scenario in which Brazil is advancing among the world's largest economies, the supply of jobs has been linked to the quest for the supply of skilled workers (SARMENTO; ABREU-E-LIMA; MORAES FILHO, 2016). Gimenez (2013) states that reporters from a major Brazilian radio station argued in July 2012 that the government should focus on teaching English in schools, given the difficulty of finding candidates for the SwB program, since most students sought scholarships in Portugal and Spain, due to their low proficiency in other languages to go to other countries. Gimenez (2013) states that only after facing these problems in SwB did the "tip of the iceberg" become visible regarding the need to promote the teaching of foreign languages in Basic Education and not only in higher education. The study by Carvalho and Maia (2015, p.18) corroborates this information, indicating that one of the main problems found in $\mathrm{SwB}$ was the "insufficient linguistic proficiency of SwB students".

Sarmento, Abreu-e-Lima and Moraes Filho (2016, p. 28, our translation) also follow this line of thought, indicating that:

[...] a policy for foreign language teaching, therefore, should consider the entire Brazilian educational system, based on the decisions made by the federal government. One cannot internationalize only higher education without considering the entire system and without checking the set of legislation and guidelines that rule the teaching of foreign languages in Brazil.

De Wit's speech (2016) is consonant with this need to invest in Basic Education. He mentions that one of the main obstacles to internationalization is the insufficient supply of foreign language teaching and low proficiency in English. He further emphasizes that the issue of language proficiency should be addressed in Basic Education and not in 
higher education, when students would have less time to devote to language learning.

Regarding the relevance of languages in the internationalization process, De Wit (2016) emphasizes the following needs:

a) to improve the proficiency in foreign languages of teachers and students;

b) to improve the quality of basic education in the teaching of foreign languages;

c) to improve the ability to offer subjects in other languages;

d) to include the possibility of studying other languages;

e) to understand that a language policy is also part of internationalization "at home" and is fundamental for the internationalization process as a whole;

f) to understand that a policy to promote multilingualism is also part of internationalization actions;

g) to understand that English is important, but other languages should also be offered, and this offer should occur in basic education.

Altenhofen (2013) indicates that the SwB program contributed to showing the need to improve the L2 proficiency of teachers and students, since most of the candidates sought Portugal or Spain as a destination country because of the language spoken in those countries. This raises awareness of the need to expand the ability to teach and learn other languages. In the same sense, we believe that $\mathrm{SwB}$ was important in developing awareness of the need for training in other languages.

With the goal of developing science, technology, and innovation, SwB also sought to foster L2 learning as a key element for the success of the program. In addition, the issue of education is directly related to this development, as proposed by the United Nations Millennium Development Goals, ${ }^{15}$ which guide actions in the international context, with proposals in the area of education.

Therefore, the question of languages has a decisive role, since, according to Romaine (2013) and Archanjo (2017), a knowledgebased society must reflect on the provision of languages in educational environments, thinking about multilingual language policies. In this context,

${ }^{15}$ More information at: http://www.un.org/millenniumgoals/ 
the phenomenon of globalization has once again placed languages in evidence, emphasizing the importance of international communication, since linguistic resources are necessary to move in spaces without borders (ARCHANJO, 2017).

However, and as shown by Finardi (2014), English still has a differentiated status when compared to other languages. The Brazilian educational reform restricts the teaching of L2s to the teaching of English. Another indication of this status of English in relation to other languages can be seen in the funding of the LwB program: while LwB-English has fellows (Capes) and American teaching assistants (Fulbright), the other languages offered by the program are not financed directly by national funds. In addition, the announcement of the Capes PrInt Call still gives prominence to English when determining that the proposals to the Call should be presented in that language. Although we recognize the importance of English for the internationalization process, we emphasize that other languages also play a relevant role and that, in our view, they have not been sufficiently recognized in language and internationalization policies.

Another discussion that should be taken into account (for the definition of policies) is the current attempt to establish a new National Curriculum for Basic Education (Base Nacional Comum Curricular - BNCC ${ }^{16}$ ) in Brazil. BNCC is a regulatory document for public and private education institutions and aims to inform the creation of school curricula and pedagogical proposals for early childhood education and elementary education. In its current $3^{\text {rd }}$ edition, ${ }^{17}$ approved after the law that makes the teaching/learning of English mandatory in basic education in Brazil referred to earlier in this text, the BNCC, unlike former versions, does not mention the contents necessary to learn in foreign languages. Instead, the document explicitly mentions the contents that must be learned in English. As such, the BNCC reinforces the hegemony of English in Brazil, thus jeopardizing the development of other L2s in basic education in Brazil.

\footnotetext{
${ }^{16}$ More information available at: http://basenacionalcomum.mec.gov.br/

${ }_{17}$ More information available at: http://portal.mec.gov.br/index.php?option $=$ com_ docman\&view $=$ download\&alias $=78231$-anexo-texto-bncc-reexportado-pdf-1\&category_ slug=dezembro-2017-pdf\&Itemid=30192
} 


\section{Internationalization and Language Policies: What is the relationship?}

This paper aimed to reflect on the relationship between the internationalization of higher education and language policies in Brazil. The analysis of language and internationalization policies embodied in national programs and agencies, such as SwB, LwB, and Capes PrInt, suggests the need to think about the role of L2s at different educational levels, as well as in the fostering of multilingualism in Brazil. Moreover, the analysis suggests that it is important to consider the role of languages in the internationalization of higher education so as to avoid oppressive models that benefit hegemonic countries of the global North (SANTOS, 2011; STEIN et al., 2016; VAVRUS; PEKOL, 2015).

Considering the role of languages in mobility programs, Archanjo (2017) questions how to strengthen the role of L2s in both Brazilian education and language and internationalization policies. One possibility is advanced by Finardi (2017b) suggesting that the intercomprehension approach may offer a relevant alternative to include other languages in the curriculum and in the offer of academic courses and actions. Another possibility is to expand the array of languages used in academic international exchanges with the use of technology, such as in the COIL approach, as suggested by Hildeblando and Finardi (2018).

Moreover, we believe that the proposal of convergent language and internationalization policies is necessary so as to integrate and promote the teaching and learning of languages at all levels of education, thus achieving the main objective of internationalization, which should be to improve teaching, research, and extension actions of a given academic community, thereby yielding benefits to most people involved, thus fighting acritical (and usually imported) models of internationalization based on hegemonic practices of the Global North.

Given the complexity of the internationalization process of higher education, we conclude that the formulation of policies to support the internationalization of education must be articulated with specific policies for the teaching, learning, and use of L2s (with changes in the current BNCC for it to become multilingual), which may in turn result in a National Policy for these languages (SARMENTO; ABREU-E-LIMA; MORAES FILHO, 2016), using knowledge in areas such as Linguistics, Education, and International Relations. In addition, we propose a reflection on 
internationalization in order to make it more equitable and sustainable for all people on this planet, thus avoiding oppressive internationalization models such as those denounced by Stein et al. (2016).

\section{Acknowledgements}

This study was financed in part by the Coordenação de Aperfeiçoamento de Pessoal de Nivel Superior - Brazil (CAPES) - Finance Code 001.

Special thanks to Fapes for research grant (Fapes Universal Edital 03/2017).

\section{Contribution of Authors}

Each author contributed to this study, as follows: Felipe Guimarães worked on the contextualization of internationalization and language policies, including the theoretical framework and literature review, as well as the institutional and governmental documents related to the main topics of this study. Kyria Finardi worked on the analysis of national policies and programs and their relation with language policies, and Janayna Casotti worked on the issues related to the definitions surrounding language policies, including their origins and developments, as well as the topics related to Portuguese as an additional language (PAL).

\section{References}

ALTENHOFEN, C. Bases para uma política linguística das línguas minoritárias no Brasil. In: NICOLAIDES, C. et al. (org.). Política e políticas linguísticas. Campinas: Pontes Editores, 2013. p. 93-116.

ANDREOTTI, V. de O.; STEIN, S.; AHENAKEW, C.; HUNT, D. Mapping interpretations of decolonization in the context of higher education. Decolonization: Indigeneity, Education and Society, Toronto, v. 4, n. 1, p. 21-40, 2015.

ARCHANJO, R. Moving globally to transform locally? Academic mobility and language policy in Brazil. Language Policy, [S.l.], v. 16, p. 291-312, 2017.

BAGNO, M.; CARVALHO, O. L. S. O potencial do português brasileiro como língua internacional. Interdisciplinar, Aracaju, Ano X, v. 22, p. 11-26, jan./jun., 2015.

BEELEN, J.; JONES, E. Defining Internationalization at home. University World News. 2015. Available at: http:/ /www.universityworldnews.com/article.php?story= 20151202144353164. Retrieved on: Nov. 2, 2016. 
BRITISH COUNCIL; FAUBAI (Associação Brasileira para Educação Internacional). Guide to Brazilian higher education courses in English 2016. Available at: https://www.britishcouncil.org/sites/default/files/guide_brazilian_highered_ courses_inenglish_limpo_indexado_2.pdf. Retrieved on: Nov. 2, 2016.

CARVALHO, J:; MAIA, R. Repensar o papel da mobilidade na cooperação internacional na Europa e no Brasil: Projeto Alísios - Relatório Final. Coimbra, 2015.

CARVALHO, S. da C.; SCHLATTTER, M. Ações de difusão internacional da língua portuguesa. Cadernos do IL, Porto Alegre, n. 42, p. 260-284, 2011. Available at: http://www.seer.ufrgs.br/index.php/cadernosdoil/article/view/26027/15240. Retrieved on: Mar. 28, 2018.

CASTRO-GÓMEZ, S. Decolonizar la universidad: la hybris del punto cero y el diálogo de saberes. In: CASTRO-GÓMEZ, S.; GROSFOGUEL, R. (org.). El giro decolonial: reflexiones para una diversidad espitémica más allá del capitalismo global. Bogotá: Siglo del Hombre Editores, 2007.

DEUTSCHER AKADEMISCHER AUSTAUSCHDIENST (DAAD). 4 anos de Ciência sem Fronteiras na Alemanha: o balanço de uma história de sucesso. Oldenburg: Flyerheaven, 2015.

DE WIT, H. Criterios para diseño y evaluación de políticas de internacionalización. In: UNICAMP INTERNATIONAL SEMINAR (CINDA): IMPACTO DE LA INTERNACIONALIZACIÓN SOBRE LA CALIDAD DE LA EDUCACIÓN SUPERIOR, 2016, Campinas. Campinas: Unicamp, 2016. Communication Material Presented.

DE WIT, H. et al. Internationalization of Higher Education in Latin America: the international dimension. Washington: World Bank, 2005. Doi: https://doi. org/10.1596/978-0-8213-6209-9

EUROPEAN PARLIAMENT. Structural and Cohesion Policies: culture and education. Bruxelas: Directorate General for Internal Policies, 2015.

FINARDI, K. R. Internacionalização crítica: possibilidades para a inclusão e (in) formação superior. A educação docente em contextos de internacionalização/ mundialização: In: JORNADA INTERNACIONAL DE LINGUÍSTICA APLICADA CRÍTICA: A LINGUÍSTICA APLICADA CRÍTICA E SEU COMPROMISSO COM A SOCIEDADE, I., 2017, Brasília. Brasília: Universidade de Brasília, 2017a. Round Table Presented.

FINARDI, K. R. What Brazil can learn from Multilingual Switzerland and its use of English as a Multilingua Franca. Acta Scientiarum, Maringá, v. 39, n. 2, p. 219-228, 2017b. Doi: https://doi.org/10.4025/actascilangcult.v39i2.30529 
FINARDI, K. R. Language Policies and Internationalisation in Brazil: The Role(s) of English as an Additional Language. In: SCIRIHA, L. (org.). International Perspectives on Bilingualism. Newcastle upon Tyne: Cambridge Scholars Publishing, 2016a. v. 1, p. 79-90.

FINARDI, K. R. Globalization and English in Brazil. In: . (org.). English in Brazil: Views, Policies and Programs. Londrina: EDUEL, 2016b. v. 1, p. 15-36.

FINARDI, K. R. English in Brazil: Views, Policies and Programs. Londrina: EDUEL, 2016c. v. 1.

FINARDI, K. R. The Slaughter of Kachru's Five Sacred Cows in Brazil: Affordances of the Use of English as an International Language. Studies in English Language Teaching, London, v. 2, n. 4, p. 401-411, 2014. Doi: https://doi. org/10.22158/selt.v2n4p401

FINARDI, K. R.; ARCHANJO, R. Reflections of Internationalization of Education in Brazil. In: INTERNATIONAL BUSINESS AND EDUCATION CONFERENCE, 2015, New York. Proceedings... New York: Clute Institute, 2015. v. 1, p. 504-510.

FINARDI, K. R.; ARCHANJO, R. Washback effects of the Science without Borders, English without Borders and Languages without Borders programs in Brazilian language policies and rights. In: SIINER, M.; HULT, F. M.; KUPISCH, T. (org.). Language policy and language acquisition planning. [S.l.]: Springer International Publishing, 2018. p. 173-185. Doi: https://doi.org/10.1007/978-3-319-75963-0_10

FINARDI, K. R.; CSILLAGH, V. Globalization and linguistic diversity in Switzerland: insights from the roles of national languages and English as a foreign language. In: LANG, P. (Org.). Advances in understanding multilingualism: a global perspective. Bern: Peter Lang GmbH, 2016. p. 59-79.

FINARDI, K. R.; DALVI, M. A. Encurtando as distâncias entre teoria-prática e universidade-escola no ensino de línguas e na formação de professores. Intersecções, Niterói, v. 5, n. 2, p. 115-127, 2012.

FINARDI, K. R.; FRANÇA, C. O Inglês na internacionalização da produção científica brasileira: evidências da subárea de linguagem e linguística. Intersecções, Niterói, v. 19, n. 2, p. 234-250, 2016.

FINARDI, K. R.; GUIMARÃES, F. F. Internacionalização, rankings e publicações em inglês: a situação do Brasil na atualidade. Estudos em Avaliação Educacional, São Paulo, v. 28, n. 68, p. 600-626, 2017. Doi: https://doi.org/10.18222/eae. v28i68.4564 
FINARDI, K. R.; ORTIZ, R. A. Globalization, Internationalization and Education: What is the Connection? IJAEDU-International E-Journal of Advances in Education, Turkey, v. 1, n. 1, p. 18-25, 2015.

FINARDI, K. R.; PREBIANCA, G. V. V.; MOMM, C. F. Tecnologia na educação: o caso da internet e do inglês como linguagens de inclusão. Cadernos do IL, Porto Alegre, v. 46, p. 193-208, 2013.

FINARDI, K. R.; PREBIANCA, G. V. V.; SCHMITT, J. English distance learning: possibilities and limitations of MEO for the flipped classroom. Revista Brasileira de Linguistica Aplicada, Belo Horizonte, v. 16, n. 2, p. 181-208, 2016. Doi: https://doi. org/10.1590/1984-639820158527

FINARDI, K. R.; SANTOS, J. M.; GUIMARÃES, F. F. A relação entre línguas estrangeiras e o processo de internacionalização: evidências da coordenação de letramento internacional de uma universidade federal. Interfaces Brasil/ Canadá, Pelotas, v.16, n.1, p. 233-255, 2016.

FINARDI, K. R.; TYLER, J. R. The role of English and technology in the internationalization of education: insights from the analysis of MOOCs. In: INTERNATIONAL CONFERENCE ON EDUCATION AND NEW LEARNING TECHNOLOGIES, $7^{\text {th }}, 2015$, Barcelona. Proceedings..., Barcelona: EduLearn15, 2015. v. 1, p. 11-18.

GARSON, K. Reframing Internationalization. Canadian Journal of Higher Education, Toronto, v. 46, n. 2, p. 19-39, 2016.

GIMENEZ, T. A ausência de políticas para o ensino de língua inglesa nos anos iniciais de escolarização no Brasil. In: NICOLAIDES, C. et al. (org.). Política e políticas linguisticas. Campinas: Pontes Editores, 2013. p. 199-218.

GIMENEZ, T.; CALVO, L.; EL KADRI, M. (ed.). Inglês como lingua franca: ensinoaprendizagem e formação de professores. Campinas: Pontes Editores, 2011.

GUIMARÃES, F. F. Programa Ciência sem Fronteiras: proposta de gestão a partir da avaliação de procedimentos e experiências discentes da Universidade Federal do Espírito Santo. 2016. 203 f. Dissertação (M.A. in Public Management) - PostGraduate Program in Public Management, Universidade Federal do Espírito Santo, Vitória, 2016.

HAMEL, R. E. L'anglais, langue unique pour les sciences? Le rôle des modèles plurilingues dans la recherche, la communication scientifique et l'enseignement supérieur. Synergies Europe, Rouen, n. 8, p. 53-66, 2013. 
HILDEBLANDO, C. A.; FINARDI, K. R. Internationalization and Virtual Collaboration: Insights from COIL Experiences. Ensino em Foco, Salvador, v. 1, n. 2 p. 19-33, 2018.

HUDZIK, J. Comprehensive internationalization: from concept to action. Washington DC: NAFSA (Association of International Educators), 2011.

INTERNATIONAL ASSOCIATION OF UNIVERSITIES (IAU). Affirming academic values in the internationalization of higher education: a call for action. 2012. Available at: https://www.insidehighered.com/blogs/globalhighered/affirmingacademic-values-internationalization-higher-education-call-action. Retrieved on: Nov. 2, 2016.

JENKINS, J. English as a lingua franca in the international university: The Politics of Academic English Language Policy. New York: Routledge, 2013. Doi: https:// doi.org/10.4324/9780203798157

KAMIENSKI, C. A. Internacionalização em casa. In: SEMINÁRIO INTERNACIONAL UNICAMP-CINDA: IMPACTO DE LA INTERNACIONALIZACIÓN SOBRE LA CALIDAD DE LA EDUCACIÓN SUPERIOR, 2016, Campinas. Campinas: Unicamp, 2016. Communication Material Presented.

KNIGHT, J. Internationalization: Elements and checkpoints (Research Monograph). Ottawa: Canadian Bureau for International Education, 1994.

KNIGHT, J. Updated definition of Internationalization. International Higher Education, Boston, n. 33, p. 2-3, Fall 2003.

KUMARAVADIVELU, B. A linguística aplicada na era da globalização. In: MOITA LOPES, L. P. da (Ed.). Por uma linguística aplicada indisciplinar. São Paulo: Parábola Editorial, 2006. p. 129-148.

LAUS, S. P. A internacionalizaçãa da educação superior: um estudo de caso da Universidade Federal de Santa Catarina. 2012. 331f. Tese (Ph.D. in Business Administration) - Universidade Federal da Bahia, Salvador, 2012.

MARTINEZ, R. English as a medium of instruction (EMI) in Brazilian higher education: challenges and opportunities. In: FINARDI, K. R. English in Brazil: Views, Policies and Programs. Londrina: EDUEL, 2016. p. 191-228.

MENEZES DE SOUZA, L. M. Políticas de Internacionalização na Educação Superior: questões e caminhos. In: ICCAL - INTERNATIONAL CONGRESS OF CRITICAL APPLIED LINGUISTICS: LANGUAGE, ACTION, AND TRANSFORMATION, 2015, Brasília. Anais... Brasília, DF: Universidade de Brasília, 2015. p. 19-21. 
MONTE MOR, W. As políticas de ensino de línguas e o projeto de letramentos. In: NICOLAIDES, C. et al. (org.). Politica e politicas linguísticas. Campinas: Pontes Editores, 2013. p. 219-235.

NICOLAIDES, C.; TILIO, R. Políticas de ensino e aprendizagem de línguas adicionais no contexto brasileiro: o caminho trilhado pela ALAB. In: NICOLAIDES, C. et al. (org.). Politica e políticas linguísticas. Campinas: Pontes Editores, 2013. p. 285-305.

NÓBREGA, M. H. da. Políticas linguísticas e internacionalização da língua portuguesa: desafios para a inovação. Revista de Estudos da Linguagem, Belo Horizonte, v. 24, n. 2, p. 417-445, 2016. Doi: https://doi.org/10.17851/2237-2083.24.2.417445

PORCINO, M. C.; FINARDI, K. R. Globalization and internationalization in ELT: methodology, technology and language policy at a crossword in Brazil. In: INTERNATIONAL CONFERENCE OF EDUCATION, RESEARCH AND INNOVATION (ICERI2014), 2014, Madri.. Proceedings... Madri: IATED, 2014. v. 1 , p. $1-11$

PREBIANCA, G. V. V.; CARDOSO, G. L.; FINARDI, K. R. Hibridizando a educação e o ensino de inglês: questões de inclusão e qualidade. Revista do GEL, São Paulo, v. 11, n. 2, p. 47-70, 2014.

RAJAGOPALAN, K. Política linguística: do que é que se trata, afinal? In: NICOLAIDES, C. et al. (org.). Política e políticas linguisticas. Campinas: Pontes Editores, 2013. p. 19-42.

RIBEIRO DA SILVA, E. A pesquisa em política linguística: histórico, desenvolvimento e pressupostos epistemológicos. Trabalhos em Linguística Aplicada, Campinas, v. 52, n. 2, p. 289-320, 2013. Doi: https://doi.org/10.1590/S010318132013000200007

RICENTO, T. An introduction to Language Policy: theory and method. Malden: Blackwell Publishing, 2006.

ROBERTSON, S. Critical response to special section: international academic mobility. Discourse, Toronto, v. 31, n. 5, p. 641-647, 2010. Available at: https:// susanleerobertson.files.wordpress.com/2012/07/2010-robertson-mobilitydiscourse.pdf. Retrieved on: Nov. 2, 2016.

ROMAINE, S. Keeping the promise of the millennium development goals: why language matters. Applied Linguistics Review, [S.l.], v.4, n. 1, p. 1-21, 2013.

SANTOS, B. de S. Epistemologías del sur. Utopia y Praxis Latinoamericana, Zulia, Venezuela, v. 16, n. 54, p. 17-39, 2011. 
SARMENTO, S.; ABREU-E-LIMA, D.; MORAES FILHO, W. Do inglês sem fronteiras ao idioma sem fronteiras: a construção de uma política linguística para a internacionalização. Belo Horizonte: Editora UFMG, 2016.

SHOHAMY, E. Language Policy: hidden agendas and new approaches. New York: Routledge, 2006. Doi: https://doi.org/10.4324/9780203387962

SOUZA, M. M. M. F. Avaliação das políticas linguísticas implantadas no Brasil e os programas de mobilidade acadêmica em contexto de internacionalização. Revista Ciências Humanas, Florianópolis, v. 7, n. 2, p. 42-59, 2014.

SPOLSKY, B. Language Policy: key topics in Sociolinguistics. Cambridge: Cambridge University Press, 2004.

STEIN, S.; ANDREOTTI, V.; BRUCE, J.; SUŠA, R. Towards Different Conversations About the Internationalization of Higher Education. Comparative and International Education / Éducation Comparée et Internationale, Oxford, v. 45, article 2, 2016. Available at: http://ir.lib.uwo.ca/cie-eci/vol45/iss1/2. Retrieved on: May 20, 2017.

TAQUINI, R.; FINARDI, K. R.; AMORIM, G. English as a Medium of Instruction at Turkish State Universities. Education and Linguistics Research, Las Vegas, v. 3, n. 2, p. 35-53, 2017. https://doi.org/10.5296/elr.v3i2.11438

VAVRUS, F.; PEKOL, A. Critical Internationalization: moving from theory to practice. FIRE - Forum for International Research in Education, Bethlehem, PA, v. 2, n. 2, p. 5-21, 2015.

Data de submissão: 03/05/2018. Data de aprovação: 18/01/2019. 
http://dx.doi.org/10.1590/1984-6398201913553e

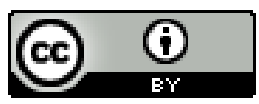

\section{ERRATA}

No manuscrito: "Internationalization and Language Policies in Brazil: What is the Relationship?", com número de DOI: http://dx.doi.org/10.1590/19846398201913553, publicado no periódico Revista Brasileira de Linguística Aplicada, v. 19, n. 2, na página 321, após:

"This study was financed in part by the Coordenação de Aperfeiçoamento de Pessoal de Nivel Superior - Brazil (CAPES) - Finance Code 001.”, inclua-se:

"Special thanks to Fapes for research grant (Fapes Universal Edital 03/2017)." 